\title{
EFEKTIVITAS FLIPPED CLASSROOM TERHADAP SIKAP DAN KETRAMPILAN BELAJAR MATEMATIKA DI SMK
}

\author{
Herry Novis Damayanti ${ }^{1}$ dan Sutama ${ }^{2}$ \\ ${ }^{1}$ SMK Negeri 1 Gedangsari Gunung Kidul Yogyakarta \\ ${ }^{2}$ Magister Administrasi Sekolah Pascasarjana UMS \\ herrynovis@gmail.com \\ sutama@ums.ac.id
}

\begin{abstract}
The aim of the research is developed attitude resposiility, and skill learning of mathematic teaching based Flipped Classroom. The final result of the research is to taste effectiveness of mathematic teaching model based Flipped Classroom. The research method is research and development that includes introduction, field study of teaching management in the school, planning and preparing Flipped Classroom model, implementation of teaching first cycle, second cycle, and third cycle, and exam of attitude, skill, and learning outcome. The average result of creativity was increased with 1,84 in the eleventh grade student in PM 1 class and 1,30 in TSM 1 class. For the responsibility, in the eleventh grade student in PM 1 class was 1,84 and 1,57 for TSM 1 class in the skill aspect also increased with 1,09 in XI PM 1 class, 1,53 in XI TSM 1 class. The result of the study was determined effectiveness of the model based attitude and skill. The effectiveness was used nnon parametric Man-Whitney test for attitude and skills show that level of significant was smaller from 0,05 to 0,003; 0,008; 0,009. The research concluded that the implementation of mathematic teaching model based Flipped Classroom at the eleventh grade student of SMKN 1 Gedangsari Gunungkidul was effective.
\end{abstract}

Key word : Flipped Classroom, skill, attitude, Mann-Whitney

\begin{abstract}
ABSTRAK
Tujuan penelitian ini adalah pengembangan sikap kreatif, tanggungjawab, dan ketrampilan belajar menggunakan model pembelajaran matematika berbasis Flipped Classroom. Hasil akhir penelitian menguji efektivitas model pembelajaran matematika berbasis Flipped Classroom terhadap sikap kreatif, tanggungjawab, dan ketrampilan belajar. Metode penelitian ini adalah penelitian dan Pengembangan yang meliputi studi pendahuluan, studi lapangan pengelolaan pembelajaran di sekolah, perencanaan dan penyusunan model Flipped Classroom, perencanaan, pelaksanaan pembelajaran siklus 1, siklus 2, dan siklus 3, dan penilaian sikap, ketrampilan, dan hasil belajar. Hasil penelitian ini adalah efektivitas model pembelajaran matematika berbasis Flipped Classroom kelas XI SMKN 1 yang menunjukkan rerata sikap kreatif terjadi
\end{abstract}


peningkatan 1,84 kelas XI PM 1 dan 1,30 kelas XI TSM 1. Sikap tanggungjawab sebesar 1,84 kelas XI PM 1 dan 1,57 kelas XI TSM 1. Aspek ketrampilan sebesar 1,09 kelas XI PM1, dan 1,53 XI TSM 1. Efektivitas model menggunakan statistik uji analisis non parametrik Mann-Whitney menunjukkan tingkat signifikansi masingmasing sebesar 0,003; 0,008; 0,009 lebih kecil dari 0,05 sehingga model pembelajaran berbasis Flipped Classroom yang diterapkan pada kelas XI SMKN 1 Gedangsari efektif untuk meningkatkan sikap kreatif, tanggungjawab, dan ketrampilan belajar.

Kata kunci : flipped classroom,sikap, ketrampilan, mann-whitney

\section{PENDAHULUAN}

Permendiknas RI No. 41 Tahun 2007 tentang Standar Proses menyatakan bahwa dalam penyelenggaraan pendidikan diperlukan guru yang mengembangkan potensi dan kreativitas peserta didik. Sedangkan dalam Permendikbud Nomor 65 tahun 2013 menyatakan bahwa karakteristik pembelajaran pada setiap satuan pendidikan terkait erat pada Standar Isi. Standar Isi memberikan kerangka konseptual tentang kegiatan belajar dan pembelajaran yang diturunkan dari tingkat kompetensi dan ruang lingkup materi. Untuk mencapai maksud tersebut diatas diperlukan pemahaman dan ketrampilan guru terhadap model-model pembelajaran

Teori pendidikan telah dikembangkan untuk membantu meningkatkan model pembelajaran. Perubahan pendidikan mulai berkembang perlahan, namun perkembangan Komputer dan teknologi jaringan selama dekade terakhir menawarkan model pendidikan baru dan cara-cara yang unik untuk terhubung dengan siswa mereka, menginformasikan, berkolaborasi, dan menilai proses pembelajaran (Thad Crews, 2014). Banyak lembagalembaga tradisional telah mengembangkan kapasitas mereka dalam pembelajaran online namun disisi lain tetap mempertahankan elemen penting dari tatap muka tradisional.

Berdasarkan hasil observasi awal peneliti pada siswa kelas XI SMKN 1 Gedangsari tentang model belajar matematika. Sebagian besar siswa mengikuti pembelajaran, tanpa tahu materi yang akan diajarkan pada pertemuan tersebut. Siswa secara pasif menunggu materi yang akan disampaikan oleh guru, model pembelajaran bersifat monoton sehingga peserta didik kurang termotivasi untuk belajar. Sebagian besar pola pembelajaran masih bersifat transmisif, guru mentransfer dan menyampaikan konsep-konsep secara langsung kepada peserta didik.

Siswa secara pasif “menyerap” struktur pengetahuan yang diberikan guru pada hari tersebut. Guru menjadi sumber belajar pertama dan utama dalam pembelajaran matematika. Hal tersebut terjadi karena peserta didik belum mampu untuk diarahkan sebagai subyek dalam belajar. Fasilitas sekolah yang menunjang pembelajaran matematika juga belum tersedia secara maksimal seperti belum tersedianya media-media pembelajaran matematika. Hal ini mengakibatkan siswa pada umumnya hanya bisa mencapai tingkat penanaman konsep (mengingat dan memahami) materi yang disampaikan oleh guru dan dikategorkan dalam kategori rendah dalam Taksonomi Blooom, tanpa bisa menjangkau pada tingkat selanjutnya seperti mengaplikasikan, menganalisis, mengevaluasi, dan mencipta.

Berdasarkan uraian di atas peneliti merasa perlu mengembangkan model pembelajaran 
matematika berbasis Flipped Classroom pada siswa kelas XI Sekolah Menengah Kejuruan (SMK) untuk meneliti sejauh mana efektivitas siswa dalam pembelajaran Matematika. Model Pembelajaran berbasis Flipped Classroom adalah salah satu model pembelajaran yang berpusat pada siswa untuk meningkatkan efektifitas pembelajaran. Dahulu para pendidik umumnya menggunakan model pembelajaran ceramah, dimana model pembelajaran ceramah mencerminkan pembelajaran yang berpusat pada guru. Pembelajaran kemudian beralih pada model alternative yang disebut Flipped Classroom. Menurut Graham Brent Johnson (2013) Flipped Classroom merupakan model pembelajaran dengan cara meminimalkan jumlah instruksi langsung tapi memaksimalkan interaksi satu-satu. Strategi ini memanfaatkan teknologi yang mendukung materi pembelajaran tambahan bagi siswa yang dapat diakses secara online maupun offline kapanpun dan dimanapun. Sedangkan waktu pembelajaran di kelas digunakan siswa untuk berkolaborasi dengan rekan-rekan proyek, keterampilan praktik, dan menerima umpan balik tentang kemajuan mereka.

Model Flipped Classroom memberikan apa yang umumnya di lakukan di kelas dan apa yang umumnya dilakukan sebagai pekerjaan rumah kemudian dibalik atau ditukar. Sebelumnya siswa datang ke kelas untuk mendengarkan penjelasan guru selanjutnya mereka pulang untuk mengerjakan latihan soal. Sekarang yang terjadi adalah siswa membaca materi, melihat video pembelajaran sebelum mereka datang ke kelas dan mereka mulai berdiskusi, bertukar pengetahuan, menyelesaikan masalah, dengan bantuan siswa lain maupun guru, melatih siswa mengembangkan kefasihan prosedural jika diperlukan, inspirasi dan membantu mereka dengan proyek-proyek yang menantang dengan memberikan kontrol belajar yang lebih besar.

Peneliti berharap dengan pengembangan model pembelajaran matematika berbasis Flipped Classroom menjadi salah satu alternatif untuk mengembangkan potensi kreativitas siswa, memupuk rasa tanggungjawab, serta meningkatkan ketrampilan belajar. Tujuan penelitian adalah menguji efektivitas model pembelajaran matematika berbasis Flipped Classroom pada siswa kelas XI di Sekolah Menengah Kejuruan Negeri 1 Gedangsari Gunungkidul dilihat dari aspek sikap kreatif, sikap tanggungjawab, dan ketrampilan belajar matematika.

\section{METODE}

Penelitian secara keseluruhan ini termasuk dalam Penelitian dan Pengembangan. Pada artikel ini penelitian yang digunakan adalah desain penelitian evaluative. Menurut Sutama (2012:183), penelitian dan pengembangan adalah suatu proses atau langkah-langkah untuk mengembangkan suatu produk baru atau menyempurnakan produk yang telah ada, yang dapat dipertanggungjawabkan. Subjek penelitian ini adalah siswa kelas XI yang terlibat secara langsung terhadap model pembelajaran yang diterapkan di Sekolah Menengah Kejuruan Negeri 1 Gedangsari, Gunungkidul. Siswa kelas XI TSM 2 sebagai sampel ujicoba terbatas yang berjumlah 8 orang, siswa kelas XI PM 2 sebagai sampel ujicoba lebih luas yang berjumlah 24 orang dan kelas XI TSM 1 dan XI PM 1 sebagai pelaksanaan model yang berjumlah 23 dan 25 orang.

Teknik pengumpulan data dengan dokumentasi, observasi partisipasif, wawancara mendalam, dan rubrik penilaian sikap dan ketrampilan dan tes. Mengumpulkan seluruh data 
hasil wawancara, observasi, dan studi literatur berupa catatan, dokumen dan penilaian tentang pengembangan draft model pembelajaran Flipped Classroom , uji coba terbatas, revisi dan ujicoba lebih luas, dan pelaksanaan penelitian.

Proses penelitian adalah validasi produk terlebih dahulu oleh dosen pembimbing, uji coba terbatas siswa kelas XI TSM 2 berjumlah 8 orang, dan kelas XI PM2 berjumlah 25 orang sebagai sampel ujicoba lebih luas. Pengumpulan data dalam uji coba produk penulis menggunakan pengujian dan skala objektif untuk mencari data-data terkait yang diperlukan, berupa: catatan selama observasi, daftar guru, materi pelajaran, dan media pembelajaran yang digunakan (Sutama, 2012:96). Penilaian Produk diujikan pada seluruh siswa kelas XI yang berjumlah 139 orang. Data diperoleh hasil observasi aktifitas fasilitator hasil observasi kemampuan guru, saran/ tanggapan dalam menerapkan model pembelajaran Flipped Classroom, dan skor penilaian masing masing aspek yang dinilai.

Teknik analisa data menurut Bogdan\&Biklen dalam moleong (2013:248), berupa angket penilaian yang dikumpulkan selanjutnya dianalisis berdasarkan aspek yang dinilai dan skor yang diperoleh. Teknik analisa data juga menggunakan uji hipotesis non parametrik MannWhitney untuk menguji efektivitas model pembelajaran berbasis Flipped Classroom terhadap sikap kreatif, tanggungjawab, dan ketrampilan belajar.

\section{HASIL DAN PEMBAHASAN}

Sikap belajar matematika diamati pada aspek kreatif dan tanggungjawab menunjukkan peningkatan dari siklus pertama, kedua, dan ketiga. Rerata penilaian sikap kreatif kelas XI PM1 meningkat sebanyak 1,84 dilihat dari kondisi awal dengan rerata 1,40 dan pada siklus ketiga sebanyak 3,24 atau $36 \%$ menjadi kondisi akhir 98 \%. Peningkatan sikap tanggungjawab menunjukkan peningkatan 1,84 atau dari 56\% menjadi 96\%. Hasil peningkatan rerata nilai ketrampilan meningkat sebesar 1,09 dari kondisi awal dengan rerata 1,52 atau meningkat pada siklus pertama sebesar 56\% menjadi 96\%. Sikap tanggungjawab kelas XI TSM1, terlihat mengalami kenaikan dari siklus pertama sebesar 30\% menjadi 81\%. Penilaian sikap tanggungjawab meningkat sebesar 1,57 atau dari 70\% menjadi100\%. Peningkatan aspek tanggungjawab meningkat sebesar 1,53. Peningkatan aspek ketrampilan terjadi peningkatan rerata sebesar 1,09 dan 1,53. Hal ini juga didukung oleh Betty Love et al (2014) yang menguji aspek kinerja mahasiswa pada ujian kedua terhadap ujian pertama, terjadi perubahan skor bagi mahasiswa yang menggunakan model pembelajaran berbasis Flipped Classroom dengan nilai signifikansi 0,034. Sehingga dapat diambil kesimpulan bahwa dengan menerapkan model pembelajaran berbasis Flipped Classroom dapat meningkatkan aspek ketrampilan dan kinerja siswa.

Pembelajaran di kelas pada umumnya guru bertindak sebagai penyedia informasi dan sebagai memimpin kelas. Sementara model pembelajaran Flipped Classroom dapat diimplementasikan seperti kegiatan think-pair-share di mana siswa berinteraksi dengan rekan-rekan mereka, sedangkan instruktur berfungsi sebagai fasilitator yang membantu menyelesaikan tugas. Penelitian ini mendukung penelitian sebelumnya yang dilakukan oleh Stephanie et al (2015) yang menyatakan bahwa literatur bidang ilmu pengetahuan telah mendorong dosen dan instruktur untuk menggunakan model pembelajaran yang membutuhkan keterlibatan siswa dalam pergeseran materi dari pasif menjadi aktif, dimana siswa secara fisik 
terlibat dalam kegiatan pembelajaran, membangun pengetahuan, dan mahasiswa diwajibkan memiliki output baru yang melampaui informasi yang disajikan di kelas. Pembelajaran Flipped Classroom membentuk interaksi antara siswa dengan siswa maupun anatar siswa dengan guru untuk

Penilaian yang dilakukan pada model pembelajaran berbasis Flipped Classroom tidak hanya dilaksanakan pada akhir kompetensi akan tetapi dilaksanakan selama proses belajara mengajar di kelas dilaksanakan. Hal ini sejalan dengan penelitian Jacob Enfield (2013) yang mengungkapkan penilaian formatif dan sumatif sebaiknya dimasukkan dalam kegiatan pembelajaran tatap muka yang bermakna. Penelitian lain juga diungkapakan Guoqing Zhou (2014) yang mengungkapkan bahwa penilaian komprehensif merupakan bagian yang tidak terpisahkan dari Flipped Classroom, kegiatan ini meliputi penilaian proses pemahaman, proses penerapan, dan menganalisis melalui kegiatan presentasi, laporan hasil belajar, dan evaluasi diri. Penilaian model pembelajaran berbasis Flipped Classroom dilaksanakan dalam awal pembelajaran, selama proses pembelajaran, dan akhir pembelajaran di kelas.

Hasil observasi pada kegiatan pembelajaran dengan model Flipped Classroom menunjukkan peningkatan aspek sikap dan ketrampilan siswa dalam menerapkan konsep Barisan dan Deret serta terlibat lebih aktif dalam kegiatan pemecahan masalah. Hal ini sejalan dengan penelitian Jacob Enfield (2013) yang menunjukkan bahwa siswa lebih percaya diri terhadap kegiatan di kelas, siap menerima kegiatan belajar dengan motivasi yang lebih baik dari model pembelajaran biasa. Hal tersebut menunjukkan bahwa dengan model pembelaaran berbasis Flipped Classroom dapat meningkatkan motivasi, keaktifan, dan ketrampilan belajar.

Hasil observasi siklus 1, siklus 2, dan siklus 3 menunjukkan peningkatan rerata sikap kreatif, sikap tanggungjawab dan ketrampilan belajar yang lebih baik daripada penggunaan model pembelajaran biasa. Hal ini didukung oleh penelitian Walid Mahmoud Sdouh (2013) tentang perbedaan rerata prestasi, ketrampilan, dan sikap kreatif penggunaan model pembelajaran brainstorming dan computer menunjukkan hasil yang signifikan dan efektif. Hal ini bermakna bahwa model pembelajaran berbasis Flipped Classroom dengan memanfaatkan teknologi dan brainstorming dapat meningkatkan aspek kognitif, afektif, dan psikomotor.

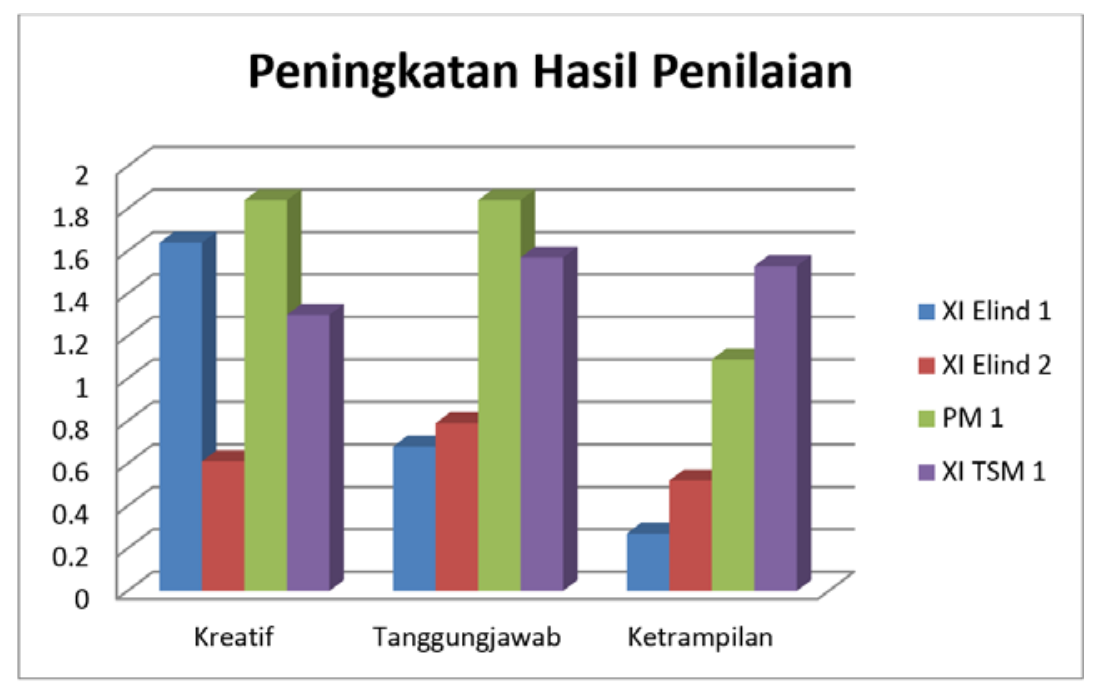

Gambar 1. Peningkatan hasil Penilaian Sikap dan Ketrampilan 
Hasil rerata sikap kreatif berdasarkan kondisi awal, siklus 1, siklus 2, dan siklus 3 menunjukkan peningkatan sebesar 1,84 dan 1,30, sedangkan rerata sikap tanggungjawab menunjukkan peningkatan sebesar 1,84 pada kelas XI PM 1 dan 1,57 pada kelas XI TSM1. Hal ini mendukung penelitian oleh Betty Love et al (2014) yang menguji pada latihan pertama sampai ketiga terdapat skor yang berbeda secara signifikan pada model Flipped Classroom dengan nilai signifikansi 0,012. Hal ini menunjukkan bahwa dengan penerapan model pembelajaran berbasis Flipped Classroom berdampak signifikan terhadap aspek sikap siswa.

Untuk menguji efektivitas model pembelajaran dilihat dari penilaian sikap kreatif dan tanggungjawab, digunakan uji statitik uji non parametrik Mann-Whitney karena asumsi kenormalan tidak dapat dipenuhi. Asumsi normalitas data tidak dapat dipenuhi karena penyebaran data menjauhi garis regresi. Selanjutnya akan di uji apakah perbedaan rata-rata tersebut berbeda secara signifikan menggunakan uji Mann-Whitney.

Tabel 1. Uji Statistik Non-Parametrik

\begin{tabular}{cccc}
\hline & Kreatif & Tanggungjawab & Ketrampilan \\
\hline Mann-Whitney U & 731.000 & 775.500 & 763.500 \\
Asymp. Sig. (2-tailed) & .003 & 0.008 & 0.009 \\
\hline
\end{tabular}

Berdasarkan uji statistik di atas terlihat bahwa nilai signifikansi sebesar masing-masing aspek yaitu 0,003; 0,008; 0,009 kurang dari taraf signifikansi 0,05 sehingga dapat disimpulkan bahwa terdapat perbedaan yang nyata dari hasil penilaian sikap kreatif, sikap tanggungjawab, dan ketrampilan belajar matematika antara model pembelajaran biasa dengan model Flipped Classroom atau model pembelajaran Flipped Classroom efektif untuk meningkatkan sikap kreatif, tanggungjawab, dan ketrampilan belajar siswa. Penelitian ini sejalan dengan Betty Love et al (2014) yang menguji efektivitas dua metode pengajaran (Kuliah Tradisional dan Flipped Classroom) pada mata kuliah aljaba Linear Sophomore tingkat menengah di Metropolitan University. Analisis yang dilakukan adalah menggunakan uji non-parametrik Mann-Whitney, karena asumsi kenormalan tidak terpenuhi. Hasil uji hipotesis menunjukkan bahwa nilai signifikansi 0,00294 lebih kecil dari taraf signifikansi 0,05 sehingga mendukung hipotesis alternatif yang artinya kelas Flipped Classroom berkontribusi signifikan terhadap perkembangan mahasiswa pada kuliah tersebut. Hal ini dapat dimaknai bahwa untuk menguji efektivitas model pembelajaran berbasis Flipped Classroom menggunakan statistik uji analisis kovariansi (ankova), namun jika asumsi kenormalan tidak dipenuhi dapat menggunakan uj non-parametrik Mann-Whitney.

\section{SIMPULAN}

Efektivitas model pembelajaran berbasis Flipped Classroom menggunakan peningkatan rerata sikap kreatif, sikap tanggungjawab, dan ketrampilan belajar yang meningkat masing masing sebesar 1,84; 1,84; 1,09 pada kelas XI PM 1. Sedangkan pada kelas XI TSM 1 terjadi peningkatan 1,30; 1,57; 1,53 pada penilaian ketrampilan. Pengujian efektivitas model juga menggunakan analisis non parametrik Mann-Whitney yang menunjukkan nilai signifikansi masing-masing 0,003; 0,008; 0,009 kurang dari taraf signifikansi 0,05. Sehingga model Flipped Classroom efektif untuk menguji sikap kreatif, tanggungjawab, dan ketrampilan belajar siswa. 


\section{DAFTAR PUSTAKA}

Betty Love, Angie Hodge, Neal Grandgennet and AndrewW. Swift. 2014. Student Learning and Perceptions in a Flipped Linear Algebra Course. International Journal of Mathematic Education in Science and Tecnology.Vol 45, No. 3, pp 317-324. Francis.

Guoqing Zhou \& Xuefeng Jiang. 2014. Theoritical Research and Instructional Design of the Flipped Classroom. Journal Of Applied Mechanics and Materials. Vols. 543-547, pp 4312-4315. Switzerland.

Jacob Enfield. 2013. Looking at the impact of the Flipped Classroom Model of Instruction on Undergraduate Multimedia Student at CSUN. TechTrends. Vol 57. No. 6 pp. 14-18.

Johnson, Graham Brent. 2013. Student Perceptions Of The Flipped Classroom. Columbia: The University Of British Columbia.

Stephanie Butler Velegol, Sarah E Zappe \& Emily Mahoney, 2015. The Evolution of a Flipped Classroom: Evidence-Based recommendations. American Society For Engineering education. Pennsylvania.

Sutama. 2015. Metode Penelitian Pendidikan. Surakarta. Fairuz Media.

Walid Mahmoud Sdouh. The Effect of using The Strategies of Brainstorming and Computer Education in academic achievement and the Development of Creative Thinking skills of sixth grade Student in Jordan and Their Attitudes Towards Learning Mathematics. European Scientific Journal. Vol. 9 No. 13. Pp 220 